\title{
Illegal Use of Clenbuterol in Cattle Production in México
}

\author{
Benjamin Valladares-Carranza1*, Rómulo Bañuelos-Valenzuela², \\ Silvia D. Peña-Betancourt ${ }^{3}$, Valente Velázquez-Ordoñez ${ }^{1}$, \\ Yadira Velázquez-Armenta ${ }^{4}$, Alejandro Nava-Ocampo ${ }^{4}$ \\ ${ }^{1}$ Centro de Investigación y Estudios Avanzados en Salud Animal, Facultad de Medicina Veterinaria y Zootecnia, \\ Universidad Autónoma del Estado de México, Unidad Académica de Medicina Veterinaria y Zootecnia, \\ Universidad Autónoma de Zacatecas, Zacatecas, México \\ ${ }^{2}$ Unidad Académica de Medicina Veterinaria y Zootecnia, Universidad Autónoma de Zacatecas, Zacatecas, \\ México \\ ${ }^{3}$ Laboratorio de Toxicología, Departamento de Producción Agrícola y Animal, Universidad Autónoma \\ Metropolitana, México, D.F., México \\ ${ }^{4}$ Pharma Reasons, Toronto, ON, Canada \\ Email: ${ }^{*}$ benvac2004@yahoo.com.mx
}

Received 12 December 2013; revised 21 January 2014; accepted 30 January 2014

Copyright (C) 2014 by authors and Scientific Research Publishing Inc.

This work is licensed under the Creative Commons Attribution International License (CC BY).

http://creativecommons.org/licenses/by/4.0/

c) (i) Open Access

\section{Abstract}

Slaughtered cattle $(n=582)$ from México State were bled for a serological screening of clenbuterol residues, using a commercial enzyme-linked immunosorbent assay (ELISA). Clenbuterol residues were found in a total of $153 / 582(26.2 \%)$ sera analysed. These results reinforced the assumption of the illegal use of clenbuterol in cattle production in México; therefore, routine screening examinations in slaughtered cattle were strongly advised considering the toxic potential for humans.

\section{Keywords}

Clenbuterol; ELISA; Cattle; México

\section{Introduction}

The clenbuterol is white, anhydrous, very soluble in water and has a highly stable dust to room temperature; its fusion point goes of $174^{\circ} \mathrm{C}$ to $175.5^{\circ} \mathrm{C}$. It has one structure chemistry related to catecholamine's able to interact with adrenergic receivers, generally of the type $\$ 2$. Chemically amino metil alpha butilamino T3 is amino 4, 5

${ }^{*}$ Corresponding author. 
diclorobenzil alcohol. It owns an average life of prolonged action, with the particularity of being able to store in liver and kidney and metabolizes by means of glucoronics reactions of $\mathrm{N}$-oxidation in hidroxyclenbuterol and conjugated [1]-[4] (Figure 1).

Long-acting $\beta$-adrenergic stimulating drugs such as clenbuterol are illegally used to promote animal growth, causing a considerable increase in muscular mass and, at the same time, a decrease in fat accumulation [1].

The effects derived from the product ingestion contaminated with CCL are muscular sleepiness of the hands, tremors, muscular nervousness, and headaches. In acute-extreme overdoses, not derived from the product ingestion with residues but a product of pharmaceuticals, an accidental overdose of the human line that contains clenbuterol, one accentuates the tachycardia, the sleepiness, the nervousness, the tremors and can have necrosis of the myocardium by diminution of the perfusion generated by the shortening of the diastole, the stage in which the irrigation of the myocardium by the coronary ones is carried out [2]-[4].

Doubtless for the producers, the inclusion of CCL in the diet of bovines has generated important gains economically; nevertheless the problems in public health and in health animal require that specialist in the sector veterinary health, doctors and epidemiologists work together to safeguard the collective health. And the SAGARPA at Federal State level also must maintain operative of monitoring and the control, for the eradication in the use of this substance [4] [5].

To authors' knowledge, data on the illegal use of clenbuterol in cattle production in México had been carried out only at the Yucatán Peninsula [6]. The present study was undertaken with the aim to identify the presence of clenbuterol residues in cattle at the slaughterhouse in México State, Central México.

\section{Materials and Method}

Between September 2012 to March 2013, blood samples were collected from 582 cattle at the Toluca slaughterhouse, México. For each sampled animal, municipality origin was recorded.

Cattle handling procedures were performed with the license of the owners. Approximately $3 \mathrm{ml}$ of blood was collected from the jugular vein.

All sera were tested for clenbuterol residues by a commercial enzyme-linked immunosorbent assay (ELISA) (RIDASCREEN ${ }^{\circledR}$ Clenbuterol Fast, R-Biopharm AG, Darmstadt, Germany) [7]. ELISA was performed by using $20 \mu \mathrm{l}$ of serum according to manufacturer's instruction. Absorbances (A) were read at $450 \mathrm{~nm}$ using a BIOTEK microplate reader (USA). Obtained percentage absorbance values were transformed to parts per trillion (ppt) of clenbuterol and ranked as 2000 - 4000, 4001 - 6000, 6001 - 8000, and >8001 ppt.

\section{Results and Discussion}

In all ELISA assays, negative and positive control suspensions (supplied in the kit) were run in each test. Clenbuterol residues were found in 153/582 (26.2\%) sera analysed. Table 1 shows the frequency values according to ELISA ranked results according with the municipality origin of cattle.

Clenbuterol has been elsewhere recognized as a cause of poisoning clinical disease in humans for many years [8] [9]. In México, up to April 2002, a total of 132 cases were recorded and related with bovine liver consumption [10]. In Mérida, Yucatán, 138 liver samples from slaughtered cattle were negative to clenbuterol residues by the gass/mass method [6]. Nowadays, clenbuterol use in cattle production is prohibited by official regulation [5].

The major advantage of ELISA in clenbuterol detection is rapid analysis and relatively simple, cheap system for detection (especially when residue levels are high), and easy to perform even with large batches [11]. These characteristics made ELISA an attractive tool for serological clenbuterol residues detection in many laboratories worldwide.

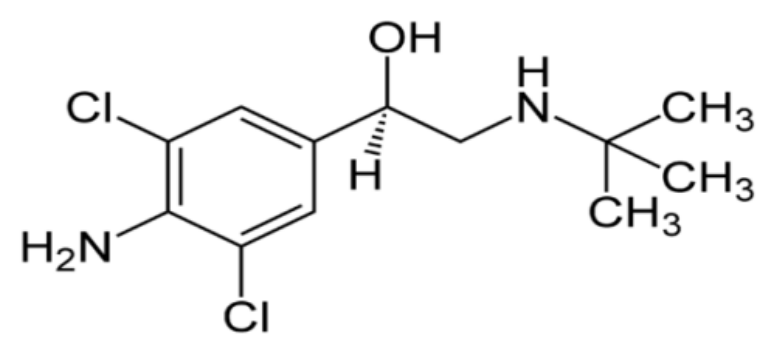

Figure 1. Chemical structure of the molecule of clenbuterol. 
Table 1. Clenbuterol residues results by ELISA, according to the Mexico state municipality of the cattle included in the study.

\begin{tabular}{|c|c|c|c|c|c|c|c|}
\hline \multirow[t]{2}{*}{ Municipality } & \multirow[t]{2}{*}{$\begin{array}{l}\text { Number of sera } \\
\text { samples }\end{array}$} & \multirow[t]{2}{*}{$\begin{array}{l}\text { Number of } \\
\text { positivity }\end{array}$} & \multirow[t]{2}{*}{$\begin{array}{c}\text { Percentage of } \\
\text { positivity }\end{array}$} & \multicolumn{4}{|c|}{ Clenbuterol ppt in sera } \\
\hline & & & & 2000 to 4000 & 4001 to 6000 & 6001 to 8000 & $>8001$ \\
\hline Almoloya de Juárez & 52 & 9 & 17.3 & 6 & 1 & 1 & 1 \\
\hline Amecameca & 2 & 2 & 100.0 & 0 & 0 & 0 & 2 \\
\hline Ecatepec & 7 & 6 & 85.7 & 1 & 0 & 1 & 4 \\
\hline Ixtlahuaca & 16 & 11 & 68.7 & 4 & 1 & 4 & 2 \\
\hline Jocotitlán & 55 & 10 & 18.1 & 6 & 1 & 1 & 2 \\
\hline Luvianos & 13 & 5 & 38.4 & 3 & 0 & 0 & 2 \\
\hline San Felipe del Progreso & 38 & 6 & 15.7 & 5 & 1 & 0 & 0 \\
\hline San José del Rincón & 20 & 6 & 30.0 & 2 & 3 & 1 & 0 \\
\hline San Simón de Guerrero & 7 & 3 & 42.8 & 2 & 1 & 0 & 0 \\
\hline Soyaniquilpan & 9 & 1 & 11.1 & 1 & 0 & 0 & 0 \\
\hline Tejupilco & 21 & 4 & 19.0 & 1 & 1 & 2 & 0 \\
\hline Temoaya & 93 & 19 & 20.4 & 10 & 0 & 3 & 6 \\
\hline Tenancingo & 3 & 1 & 33.3 & 1 & 0 & 0 & 0 \\
\hline Toluca & 150 & 44 & 29.3 & 15 & 13 & 5 & 11 \\
\hline Valle de Bravo & 1 & 1 & 100.0 & 0 & 0 & 0 & 1 \\
\hline Villa de Allende & 17 & 1 & 5.8 & 0 & 1 & 0 & 0 \\
\hline Xonacatlán & 33 & 15 & 45.4 & 10 & 0 & 2 & 3 \\
\hline Zinacantepec & 45 & 9 & 20.0 & 3 & 2 & 0 & 4 \\
\hline Total & 582 & 153 & 26.2 & 70 & 25 & 20 & 38 \\
\hline
\end{tabular}

The high percentage of clenbuterol seropositive samples (26.2\%) indicates its illegal use in cattle production in Central México. The findings of the present survey indicate the need for monitoring slaughtered cattle for human consumption.

\section{References}

[1] Cristino, A., Ramos, F. and da Silveira, M.I.N. (2003) Control of the Illegal Use of Clenbuterol in Bovine Production. Journal of Pharmaceutical and Biomedical Analysis, 32, 311-316. http://dx.doi.org/10.1016/S0731-7085(03)00073-6

[2] Jelka, P., Vulic, A., Mitac, M., Persi, N. and Milic, D. (2011) Determination of Clenbuterol Residues in Retinal Tissue of Food-Producing Pigs. Journal of Analytical Toxicology, 35, 28-31. http://dx.doi.org/10.1093/anatox/35.1.28

[3] Salquebre, G., Bresson, M., Villain, M.,Cirimile, V. and Kintz, P. (2007) Clenbuterol Determination in Calf Hair by UPLC-MS-MS: Case Report of a Fraudulent Use for Cattle Growth. Journal of Analytical Toxicology, 31, 114-118. http://dx.doi.org/10.1093/jat/31.2.114

[4] Valladares-Carranza, B., Velázquez-Ordoñez, V., Zamora-Espinosa, J.L., Aviles-Martínez, J.A., Zaragoza-Bastida, A. and Posadas-Sánchez, M.A. (2013) Implications of the Use of Clenbuterol Hydrochloride in Beef Cattle. In: Salem, A.F.Z.M., Ed., Nutritional Strategies of Animal Feed Additives, Nova Science Publishers, Inc., New York, 185-196.

[5] NOM-EM-015-ZOO-2002 (2002) Especificaciones Técnicas Para el Control del Uso de Beta-Agonistas en Los Animales. Secretaría de Agricultura, Ganadería, Desarrollo Rural, Pesca y Alimentación. Diario Oficial de la Federación. 1 de Marzo de 2002. México.

[6] Ortiz, B.J.C., Alcocer, V.V.M. and Castellanos, R.A.F. (2005) Determinación de Clenbuterol por el Método de 
Gases/Masas y su Cuantificación en Bovinos Sacrificados en dos Rastros. Técnica Pecuaria en México, 42, 57-67.

[7] R-Biopharm. RIDASCREEN ${ }^{\circledR}$ (2014) Clenbuterol Fast. Manual del Kid. R-Biopharm AG. Darmstadt. Art. No. R1701C.

[8] Brambilla, G., Cenci, T., Franconi, F., Galarini, R., Macrì, A., Rondoni, F., Strozzi, M. and Loizzo, A. (2000) Clinical and Pharmacological Profile in a Clenbuterol Epidemic Poisoning of Contaminated Beef Meat in Italy. Toxicology Letters, 114, 47-53. http://dx.doi.org/10.1016/S0378-4274(99)00270-2

[9] Pulce, C., Lamaison, D., Keck, G. and Bastuiromois, C. (1991) Collective Human Food Poisoning by clenbuterol Residues in Veal Liver. Veterinary and Human Toxicology, 33, 480-485.

[10] García, L.L. (2002) Alerta Epidemiológica por la Intoxicación en Humanos con Clenbuterol y su Empleo en la Alimentación de Ganado. Revista de Sanidad Militar, 56, 131-134.

[11] Preželj, A., Obreza, A. And Pečar. S. (2003) Abuse of Clenbuterol and Its Detection. Current Medical Chemistry, 10, 281-290. http://dx.doi.org/10.2174/0929867033368330 